\title{
Arahan Pengembangan Taman Tematik di Kecamatan Bandung Wetan dengan Pendekatan Urban Acupuncture
}

\author{
Muhammad Raihan, Putu Rudy Satiawan \\ Departemen Perencanaan Wilayah dan Kota, Fakultas Teknik Sipil, Perencanaan, \& Kebumian, \\ Institut Teknologi Sepuluh Nopember (ITS) \\ Jl. Arief Rahman Hakim, Surabaya 60111 \\ e-mail:muhammad.raihaan@yahoo.com,puturudy@yahoo.com
}

\begin{abstract}
Abstrak - Kota Bandung masih perlu menambahkan luas ruang terbuka hijau. Salah satu upaya yang dilakukan yaitu dengan cara revitalisasi taman kota dengan bentuk taman tematik. Taman tematik di Kota Bandung paling banyak terdapat di Kecamatan Bandung Wetan. Terdapat 11 taman tematik yang tersebar di Kecamatan Bandung Wetan. Berdasarkan penelitian sebelumnya, masih terdapat evaluasi terkait taman tematik sebagai ruang terbuka hijau. Penelitian ini bertujuan untuk memberikan arahan pengembangan Taman Tematik di Kecamatan Bandung Wetan dengan Pendekatan Urban Acupuncture. Metode analisis yang digunakan dalam melakukan penelitian ini adalah Content Analysis dan analisis validasi triangulasi. Content Analysis dilakukan kepada hasil wawancara 12 narasumber yang berasal dari kelompok pemerintah dan komunitas kreatif atau pengunjung terkait taman tematik untuk merumuskan faktor pengembangan taman. Sedangkan, analisis validasi triangulasi dilakukan untuk merumuskan arahan pengembangan dengan pendekatan Urban Acupuncture. Berdasarkan hasil penelitian didapatkan faktor pengembangan taman tematik di Kecamatan Bandung Wetan, yaitu (1) Kegiatan/Aktivitas; (2) Kenyamanan; (3) Partisipasi Masyarakat; (4) Kebersihan; (5) Komunitas Kreatif; (6) Kondisi fasilitas; dan (7) Kebersihan. Dengan adanya faktor pengembangan tersebut dapat diketahui faktor yang harus dikembangkan pada setiap taman tematik di Kecamatan Bandung Wetan untuk menghasilkan arahan pengembangan berdasarkan pendekatan Urban Acupuncture.
\end{abstract}

Kata Kunci-Arahan Pengembangan, Taman Tematik, Urban Acupuncture.

\section{PENDAHULUAN}

$\mathrm{K}$ OTA Bandung masih perlu menambahkan luas ruang terbuka hijau [1]. Salah satu upaya yang dilakukan yaitu dengan cara revitalisasi taman kota dengan bentuk taman tematik [2]. Taman Tematik adalah taman yang merupakan bagian dari taman kota yang dibuat dengan mengusung tema/konsep tertentu sebagai ciri khas dengan memunculkan karakter tertentu sehingga pada saat orang melihat taman tersebut sudah bisa menangkap kesan yang lebih spesifik dari fungsi taman tersebut di samping menonjolkan sisi keindahan dan kesejukannya [3]. Kecamatan Bandung Wetan merupakan kecamatan yang memiliki taman tematik terbanyak di Kota Bandung. Terdapat 11 taman tematik yang tersebar di Kecamatan Bandung Wetan [4].

Taman tematik di Kecamatan Bandung Wetan yang merupakan bagian taman kota memiliki fungsi Ruang Terbuka Hijau yang perlu dipenuhi. Berdasarkan penelitian sebelumnya, keberlanjutan taman tematik di Kecamatan Bandung Wetan diharapkan dapat terus berlangsung [5]. Namun, beberapa taman dinilai masih belum memenuhi fungsinya sebagai Ruang Terbuka Hijau [6]. Adapun beberapa aktivitas yang tidak sesuai dengan fasilitas yang telah disediakan sehingga merusak fasilitas-fasilitas yang ada pada taman tematik [7]. Pembangunan taman tematik juga dinilai bersifat top-down, sehingga mengesampingkan peran masyarakat dalam proses pembangunannya [8]. Dengan adanya kondisi tersebut maka diperlukan suatu pengembangan untuk meningkatkan kualitas taman tematik di Kecamatan Bandung Wetan tersebut.

Urban Acupuncture merupakan suatu pendekatan untuk menjawab permasalahan perkotaan guna meningkatkan kualitas lingkungan perkotaan [9]. Pendekatan Urban Acupuncture dilakukan dengan memberikan solusi penataan ruang pada skala kecil, namun dapat memberikan dampak yang signifikan pada lingkup yang lebih luas sehingga akan berdampak pada kualitas kehidupan kota [10]. Pendekatan Urban Acupuncture mensyaratkan partisipasi (kolaborasi dan iterasi) dari para pemangku kepentingan. Prinsip-prinsip yang dapat digunakan dalam melakukan pendekatan Urban Acupuncture adalah (1)Determining Sensitive Point; (2) Scenario; (3)Quick Act; (4)Citizens Participation; (5)Educating; (6)Holistic Approaches; (7)Small Scale; dan (8)Creating Places [11].

Dalam penelitian ini, Urban Acupuncture yang dimaksud adalah faktor-faktor apa saja yang berpengaruh dalam mengembangkan taman tematik di Kecamatan Bandung Wetan. Sehingga, dalam mengembangkan setiap taman tematik yang ada di Kecamatan Bandung Wetan dapat dilihat dari faktor pengembangan yang dinilai masih kurang (solusi penataan ruang skala kecil). Pendekatan Urban Acupuncture juga dilakukan dalam merumuskan arahan pengembangan taman tematik di Kecamatan Bandung Wetan.

Penelitian ini bertujuan untuk memberikan arahan pengembangan bagi setiap taman tematik di Kecamatan Bandung Wetan dengan pendekatan Urban Acupuncture. Dalam mencapai tujuan penelitian tersebut, penelitian ini dilakukan dengan cara menganalisis faktor perkembangan taman tematik di Kecamatan Bandung Wetan lalu dilanjutkan dengan merumuskan arahan pengembangan taman tematik di Kecamatan Bandung Wetan dengan pendekatan Urban Acupuncture. 


\section{METODE PENELITIAN}

\section{A. Jenis dan Pendekatan Penelitian}

Pendekatan yang digunakan dalam penelitian ini adalah pendekatan rasionalistik. Pendekatan ini bersumber dari teori dan fakta-fakta empiris yang juga menekankan pada argumentasi berdasarkan hasil kajian pustaka yang dilakukan oleh peneliti pada suatu topik penelitian pada kajian. Dalam penelitian rasionalistik, seluruh pemikiran didasari ilmu yang dipahami oleh peneliti, serta data yang digunakan untuk analisis adalah data yang dihasilkan dari observasi, kuesioner, wawancara, serta sumber-sumber pendukung lainnya. Sedangkan, jenis penelitian ini adalah penelitian kualitatif. Penelitian kualitatif bermaksud memahami fenomena tentang apa yang dialami oleh subjek penelitian misalnya perilaku, persepsi, motivasi, tindakan, dll., secara holistik dan dengan cara deskripsi dalam bentuk kata-kata dan bahasa pada suatu konteks khusus yang alamiah dan dengan memanfaatkan berbagai metode alamiah.

\section{B. Indikator dan Variabel Penelitian}

Dalam penelitian ini terdapat 5 indikator yang didapatkan dari hasil sintesis tinjauan pustaka mengenai Ruang Publik, Ruang Terbuka Hijau, Taman Kota, Taman Tematik, dan Urban Acupuncture yang digunakan sebagai pendekatan penelitian. Terdapat variabel penelitian di setiap indikator yang menjadi fokusan penelitian dari objek penelitian. Terdapat 14 variabel penelitian yang dibagi di dalam seluruh indikator penelitian.

Indikator dan variabel penelitian yang digunakan dalam penelitian ini dijabarkan pada Tabel 1 .

Tabel 1.

Indikator dan Variabel Penelitian

\begin{tabular}{cc}
\hline \hline Indikator & Variabel \\
\hline Fungsi Vegetasi (V) & Luas Taman (V1) \\
& Area Hijau (V2) \\
\hline \multirow{2}{*}{ Fungsi Sosial Budaya (SB) } & Kegiatan/ Aktivitas (SB2) \\
& Aksesibilitas (SB3) \\
& Keamanan (SB4) \\
& Kenyamanan (SB5) \\
& Komunitas Kreatif (SB6) \\
\hline Fungsi Estetika (Es) & Kesesuaian Tema (Es1) \\
& Ikon Taman (Es2) \\
& Kebersihan (Es3) \\
\hline \multirow{2}{*}{ Fungsi Ekonomi (Ek) } & Kegiatan Ekonomi (Ek1) \\
& Sarana Ekonomi (Ek2) \\
\hline Fasilitas Taman Tematik (F) & Kondisi Fasilitas (F) \\
\hline \hline
\end{tabular}

\section{Teknik Pengumpulan Data}

\section{Survei Primer}

Survei primer dilakukan dengan cara menyebarkan kuesioner, observasi, dan wawancara kepada stakeholder. Penyebaran kuesioner dilakukan dengan menghitung sampling populasi dari masyarakat Kecamatan Bandung Wetan. Dari perhitungan sampling menggunakan rumus Slovin dengan error $10 \%$ didapatkan bahwa sampling yang dibutuhkan untuk mewakili Kecamatan Bandung Wetan adalah 100 orang. Dari jumlah sampling ini dibagi rata kedalam 11 taman tematik di Kecamatan Bandung Wetan dan dibulatkan menjadi 10 orang per taman. Total jumlah responden adalah 110 responden. Responden merupakan pengunjung taman yang menilai variabel di setiap tamannya untuk menghasilkan gambaran umum di setiap tamannya. Hasil dari penyebaran kuesioner ini juga merupakan nilai dari variabel penelitian di setiap taman tematik.

Observasi dilakukan dengan mengunjungi langsung setiap taman tematik yang ada di Kecamatan Bandung Wetan untuk mendapatkan gambaran umum di taman tematik maupun sekitar taman tematik. Dengan melakukan observasi di setiap taman tematik, penulis dapat memahami lebih dalam terkait deskripsi variabel yang diteliti.

Selain itu, wawancara dilakukan kepada stakeholder terkait taman tematik di Kecamatan Bandung Wetan yang terdiri dari kelompok pemerintah dan kelompok masyarakat. Dari kelompok pemerintah terdapat Dinas Perumahan dan Kawasan Permukiman, Pertanahan dan Pertamanan (DPKP3) Kota Bandung dan juga Badan Penelitian Pembangunan, Penelitian dan Pengembangan (Bappelitbang) Kota Bandung. Sedangkan dari kelompok masyarakat terdapat para komunitas yang sering berkegiatan di setiap taman tematik atau pengunjung taman tematik. Wawancara ini dilakukan untuk mendapatkan faktor-faktor pengembangan taman tematik di Kecamatan Bandung Wetan.

\section{Survei Sekunder}

Survei sekunder dilakukan dengan cara survei instansional pada DPKP3 Kota Bandung dan Bappelitbang Kota Bandung untuk mendapatkan data yang mendukung dalam menjelaskan keberadaan taman tematik di Kecamatan Bandung Wetan. Selain itu, survei sekunder dilakukan dengan cara studi literatur dalam mendapatkan informasi dan data yang mendukung penelitian, serta best practice dalam merumuskan arahan pengembangan dengan pendekatan Urban Acupuncture.

\section{Teknik Analisis Data}

Dalam mencapai tujuan penelitian, dilakukan dengan 2 tahap sasaran, yaitu menganalisis faktor pengembangan taman tematik di Kecamatan Bandung Wetan lalu merumuskan arahan pengembangan taman tematik di Kecamatan Bandung Wetan dengan pendekatan Urban Acupuncture. Pada sasaran pertama, dilakukan dengan cara Content Analysis untuk mengetahui faktor pengembangan taman tematik di Kecamatan Bandung Wetan. Sebelumnya, dilakukan wawancara semi-terstruktur terlebih dahulu kepada stakeholder yang berasal dari kelompok pemerintah dan masyarakat. Dari kelompok pemerintah terdapat DPKP3 Kota Bandung dan Bappelitbang Kota Bandung. Sedangkan dari kelompok masyarakat diutamakan berasal dari komunitas kreatif terkait taman tematik, jika tidak terdapat komunitas disubstitusi dengan pengunjung taman yang telah lebih dari sekali mengunjungi taman. Hasil wawancara dilakukan transkrip untuk dilakukan Content Analysis dengan bantuan software Atlas.ti Versi 7.5.4.. Hasil transkrip dilakukan proses koding kepada statement yang memiliki tendensi terhadap suatu variabel. Selain itu, dilakukan juga penandaan pada variabel yang memiliki keterhubungan yang digambarkan melalui diagram. Untuk mengambil kesimpulan dari Content Analysis ini dilakukan dengan pertimbangan intensitas variabel yang sering muncul 
di atas rata-rata dan keterhubungan antar variabel dalam menentukan faktor-faktor pengembangan taman tematik di Kecamatan Bandung Wetan. Hasil akhir dari tahap analisis ini adalah faktor-faktor yang perlu dikembangkan di setiap taman tematik berdasarkan faktor pengembangan taman tematik di Kecamatan Bandung Wetan.

Pada sasaran kedua digunakan Analisis Validasi Triangulasi. Dalam melakukan triangulasi, input yang digunakan adalah faktor-faktor yang perlu dikembangkan di setiap taman tematik, gambaran umum setiap taman tematik yang berasal dari survei primer dan survei sekunder, dan studi literatur atau best practice terkait taman tematik atau Urban Acupuncture. Dalam proses triangulasi, dipertimbangkan pula prinsip-prinsip Urban Acupuncture dalam merumuskan arahan pengembangan di setiap taman tematik.

\section{HASIL DAN DISKUSI}

\section{A. Gambaran Umum Wilayah Penelitian}

Kecamatan Bandung Wetan memiliki 11 taman tematik yang tersebar di wilayahnya. Berikut adalah persebaran taman tematik yang ada di Kecamatan Bandung Wetan.

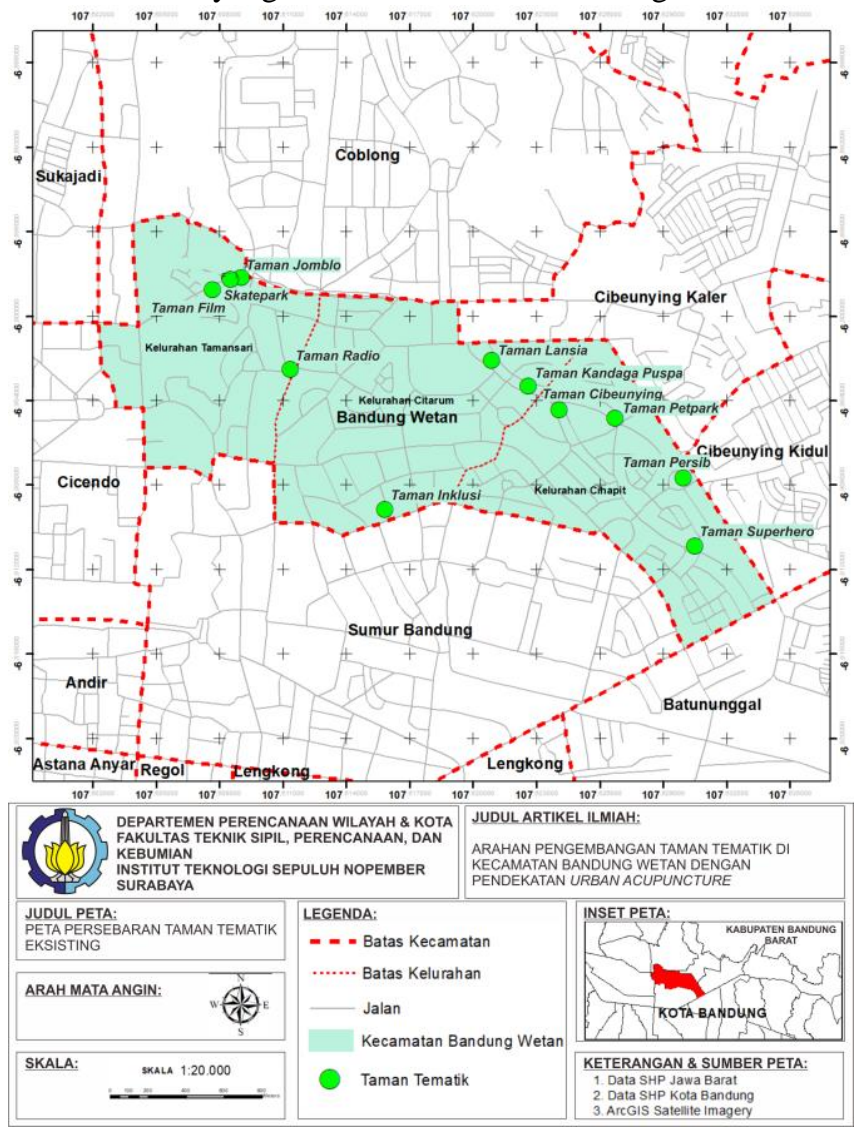

Gambar 1. Peta Persebaran Taman Tematik di Kecamatan Bandung Wetan

Berikut adalah penjelasan dari masing-masing taman tematik di Kecamatan Bandung Wetan berdasarkan variabel terkait:

\section{Taman Lansia}

Taman ini memiliki kegiatan yang beragam seperti berupa senam, zumba, dan sebagainya bagi para lanjut usia. Selain kalangan lanjut usia, taman ini diisi pula kalangan lainnya seperti anak-anak dan remaja. Taman ini cenderung ramai pengunjung, apalagi pada hari Sabtu dan Minggu. Terdapat banyak yang berjualan di sekitar taman. Terdapat komunitas yang berkegiatan di taman ini, salah satunya adalah Komunitas Line Dance Bandung.

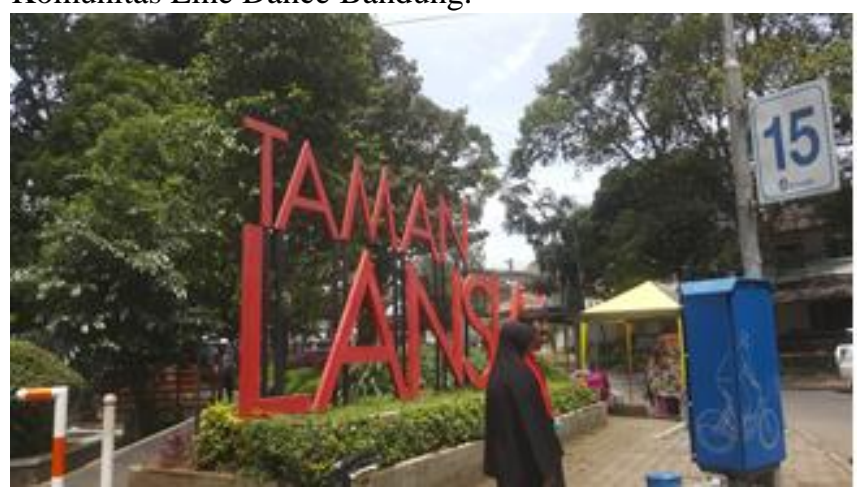

Gambar 2. Dokumentasi Taman Lansia

\section{Taman Kandaga Puspa (Pustaka Bunga)}

Taman ini memiliki tema khusus yaitu tempat konservasi tanaman hias, terutama anggrek. Dahulu, taman ini dipenuhi oleh pengunjung yang ingin belajar, berfoto, dan mengenal lebih dalam tentang tanaman hias. Akan tetapi, sekarang kondisi taman ini tidak terawat. Tidak ada kegiatan khusus yang ada di taman ini dan cenderung minim pengunjung karena kondisinya yang kurang terawat. Tidak terdapat komunitas yang secara khusus berkegiatan di taman ini.

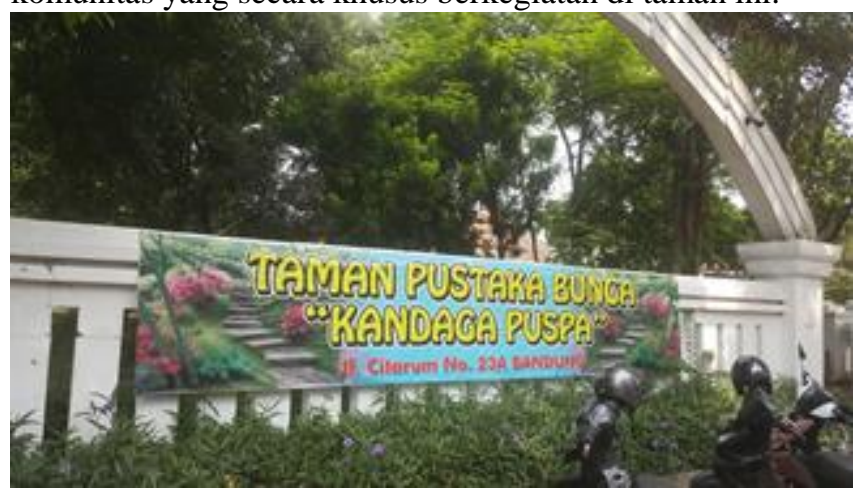

Gambar 3. Dokumentasi Taman Kandaga Puspa

\section{Taman Cibeunying}

Taman ini memiliki kegiatan utama sebagai tempat persinggahan bagi wilayah sekitarnya. Wilayah sekitar taman berupa permukiman, fasilitas pendidikan, dan juga perdagangan dan jasa seperti tempat makan. Terdapat komunitas yang berkegiatan di taman ini yaitu BARAKATAK yang merupakan komunitas ayam ketawa yang menggunakan Taman Cibeunying sebagai tempat latihan bulanannya.

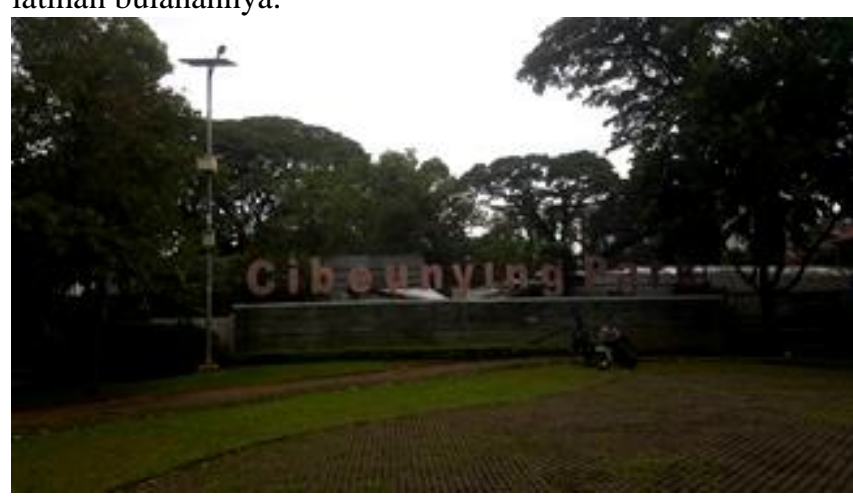

Gambar 4. Dokumentasi Taman Cibeunying

\section{Petpark (Taman Hewan)}

Taman ini menjadi tempat bagi para pemilik hewan 
peliharaan di Kota Bandung untuk mengajak hewan peliharaannya berekreasi. Di taman ini biasa terdapat kegiatan berupa melatih hewan peliharaan dan juga berkeliling taman dengan hewan peliharaan. Taman ini didominasi oleh pemilik hewan peliharaan berupa anjing. Terdapat komunitas yang biasa berkegiatan di taman ini diantaranya adalah Agility Group Bandung dan Bandung Petpark Community.

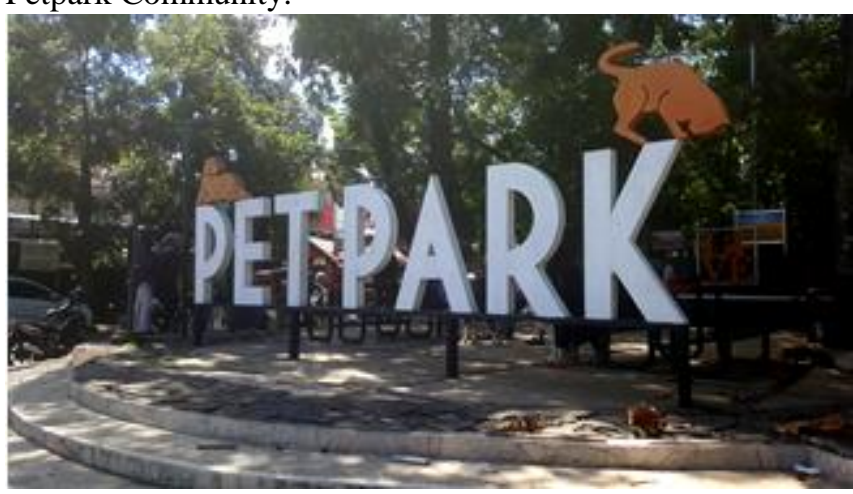

Gambar 5. Dokumentasi Petpark (Taman Hewan)

\section{Taman Jomblo (Taman Pasupati)}

Taman ini terletak di bawah Jembatan Pasupati, tepat di lampu merah Jl. Tamansari dan Jl. Cikapayang. Taman ini didesain dengan bentuk kursi berbentuk kubus yang hanya diperuntukkan untuk satu orang sehingga mewakili judul "Jomblo" pada taman ini. Kegiatan yang ada di taman ini berupa tempat persinggahan bagi para pedagang lampu merah. Tidak ada kegiatan khusus di taman ini. Tidak terdapat komunitas khusus yang berkegiatan di taman ini.

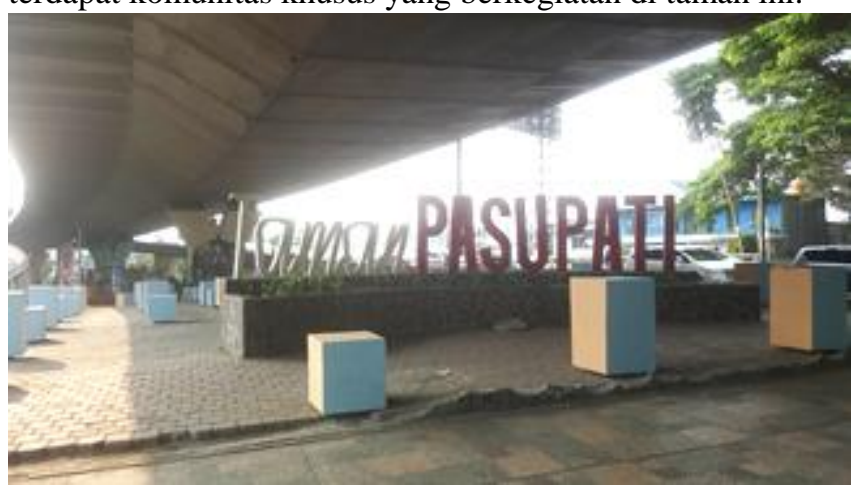

Gambar 6. Dokumentasi Taman Jomblo (Pasupati)

\section{Skatepark}

Taman ini berada tepat bersebelahan dengan Taman Jomblo. Berbeda dengan Taman Jomblo yang tidak memiliki kegiatan khusus, taman ini memiliki kegiatan khusus berupa skateboarding. Taman ini biasa dijadikan sebagai tempat event-event skateboarding di Kota Bandung. Taman ini diisi dengan berbagai komunitas skateboard di Kota Bandung, salah satunya adalah Baleendah Skateboarding Community.

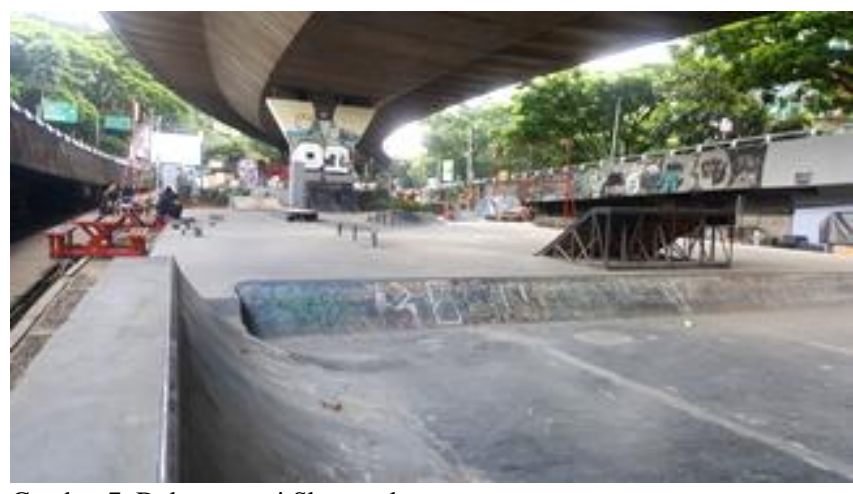

Gambar 7. Dokumentasi Skatepark

\section{Taman Film}

Taman ini mempunyai fasilitas khusus yaitu berupa videotron berukuran 4x8 m yang digunakan sehari-hari untuk penayangan film dari jam 8 pagi hingga 4 sore. Taman ini dahulu sering digunakan untuk event perfilman yang diadakan oleh komunitas film di Kota Bandung, salah satunya adalah Komunitas Ruang Film. Dari tahun 2015 hingga 2017 komunitas ini rutin mengadakan event tahunan yaitu Festival Taman Film Bandung.

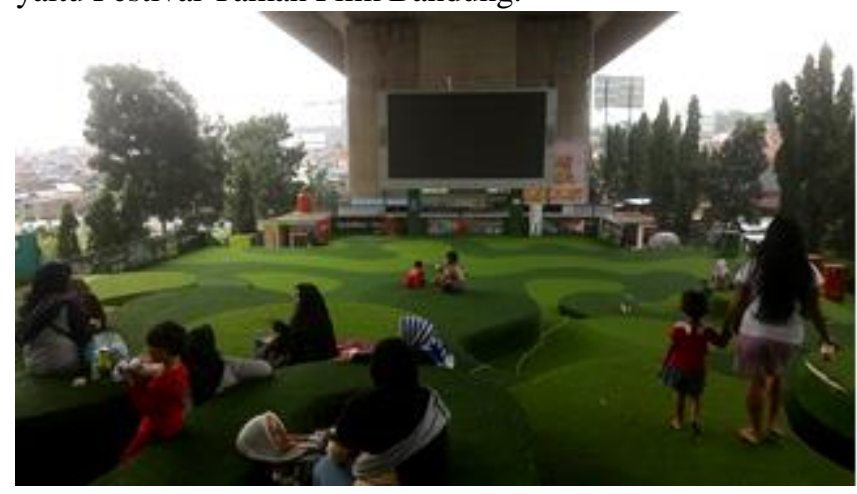

Gambar 8. Dokumentasi Taman Film

\section{Taman Superhero}

Taman ini memiliki kegiatan utama yaitu sebagai tempat rekreasi bagi anak-anak usia dini. Fasilitas permainan yang tersedia di taman ini membuat anak-anak menggunakan taman ini sebagai tempat rekreasi. Selain itu, terdapat patung-patung superhero yang menambah daya tarik taman ini bagi para anak-anak. Tidak terdapat komunitas yang secara khusus berkegiatan di taman ini.

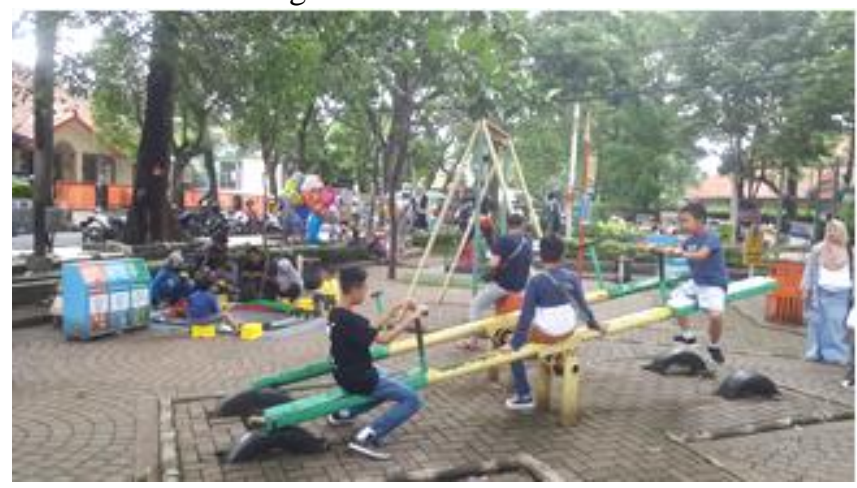

Gambar 9. Dokumentasi Taman Superhero

\section{Taman Persib (Lapang Supratman)}

Taman ini memiliki kegiatan khusus berupa olahraga. Terdapat fasilitas yang mendukung untuk kegiatan olahraga di taman ini berupa lapangan futsal, jogging track, dan juga alat calisthenic dan fitness. Terdapat komunitas yang rutin 
berkegiatan di taman ini setiap harinya, yaitu BARSTARD (Bandung Street Workout Addict). Komunitas ini berperan aktif dalam melakukan perawatan dan juga pengadaan alat di taman ini.

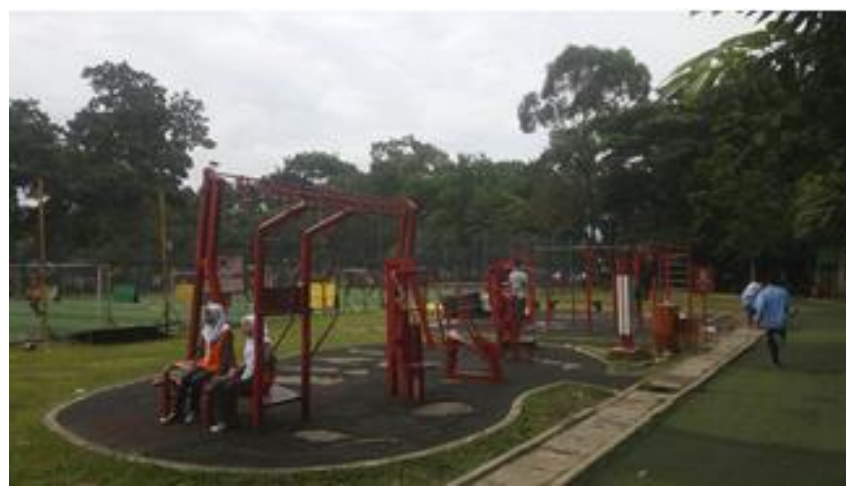

Gambar 10. Dokumentasi Taman Persib

\section{Taman Radio}

Taman ini merupakan taman yang dibangun atas inisiasi Persatuan Radio Siaran Swasta Nasional Indonesia (PRSSNI) Jawa Barat agar dapat melaksanakan kegiatan. Tidak ada kegiatan khusus yang terjadi di taman ini. Taman ini biasa digunakan sebagai tempat persinggahan bagi wilayah sekitarnya. Diketahui terdapat kampus Universitas Islam Bandung (UNISBA). Tidak ditemukan komunitas yang secara khusus berkegiatan di taman tersebut.

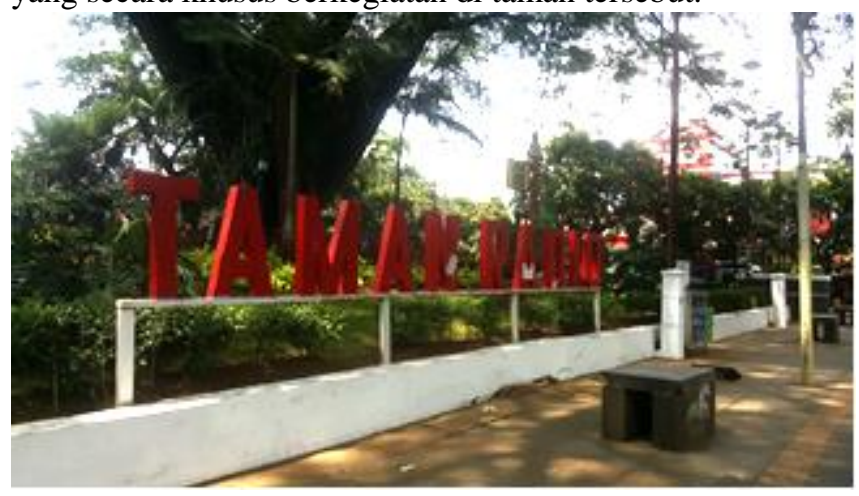

Gambar 11. Dokumentasi Taman Radio

\section{Taman Inklusi}

Taman ini dibangun sebagai tempat rekreasi bagi para penyandang disabilitas. Tidak dapat kegiatan khusus yang terdapat di dalam taman ini dan cenderung sepi pengunjung. Tidak ditemukan pula komunitas yang secara khusus berkegiatan di taman ini.

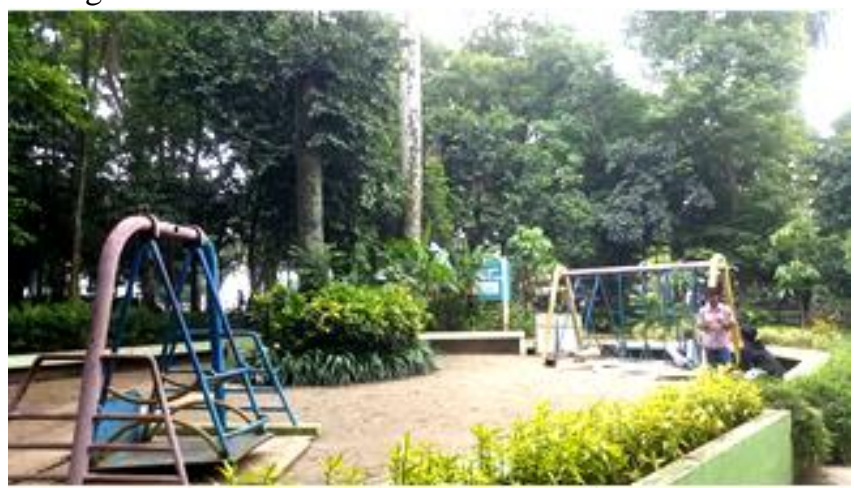

Gambar 12. Dokumentasi Taman Inklusi

\section{B. Analisis Faktor Pengembangan Taman Tematik di Kecamatan Bandung Wetan}

Pada tahap analisis ini dilakukan Content Analysis untuk mencari faktor pengembangan taman tematik di Kecamatan Bandung Wetan. Untuk mengambil kesimpulan variabel penelitian mana yang akan dijadikan faktor pengembangan, dilakukan koding pada transkrip wawancara yang dilakukan kepada 12 narasumber. Narasumber tersebut terdiri dari 2 orang pemerintah dan 10 orang yang mewakili setiap taman tematik. Penarikan kesimpulan didasarkan pada intensitas variabel yang sering muncul dan juga keterhubungan antar variabel dari hasil koding yang dilakukan. Berdasarkan intensitasnya, rekapitulasi koding adalah sebagai berikut:

\begin{tabular}{|l||l|r|r|}
\hline \multicolumn{2}{|c|}{ Code Manager [HU: Coding Transkrip] } \\
Codes Edit Miscellaneous \\
Coutput View
\end{tabular}

Gambar 13. Intensitas Koding Variabel

Berdasarkan intensitasnya, terdapat 5 variabel yang sering muncul di atas rata-rata, yaitu (1) Kegiatan/Aktivitas; (2) Kenyamanan; (3) Partisipasi Masyarakat; (4) Kebersihan; dan (5) Komunitas Kreatif. Sedangkan, berdasarkan keterhubungan variabel berdasarkan hasil koding transkrip dapat divisualisasikan seperti berikut:

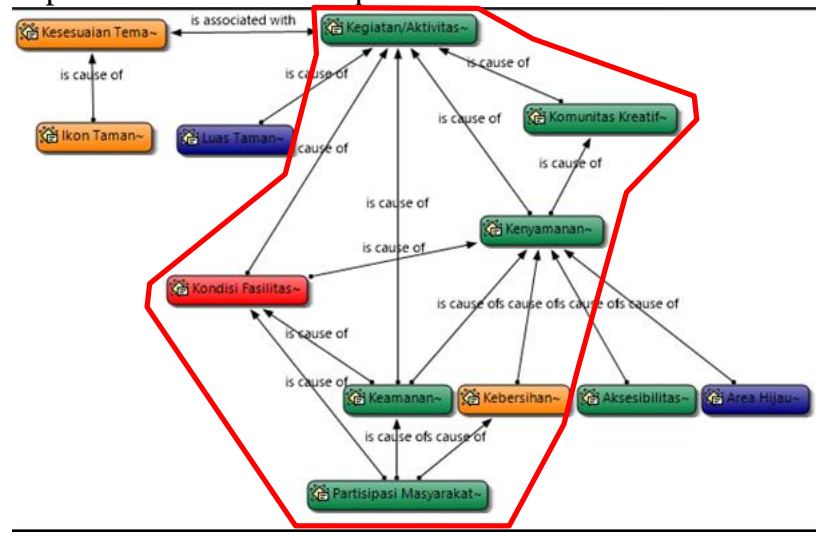

Gambar 14. Keterhubungan Variabel

Jika diambil kesimpulan berdasarkan intensitas dan keterhubungannya, maka terdapat tambahan 2 variabel yang terhubung di dalam 5 variabel yang intensitasnya di atas rata-rata, yaitu (6) Kondisi fasilitas dan (7) Kebersihan.

Telah didapatkan 7 variabel yang menjadi faktor pengembangan taman tematik di Kecamatan Bandung Wetan. Ketujuh faktor pengembangan dibandingkan dengan nilai variabel dari hasil kuesioner responden untuk mengetahui faktor yang kurang di setiap taman tematik.

1. Taman Lansia 


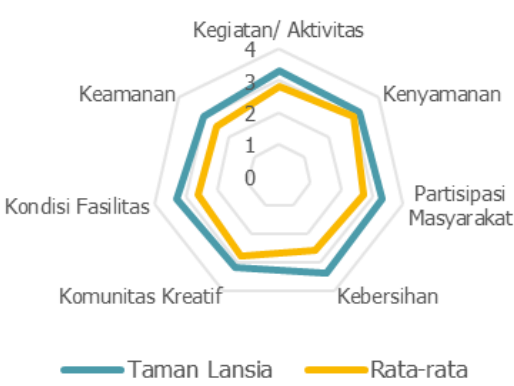

Gambar 15. Faktor Pengembangan Taman Lansia

Pada Taman Lansia, tidak terdapat kekurangan di setiap faktor pengembangannya.

\section{Taman Kandaga Puspa}

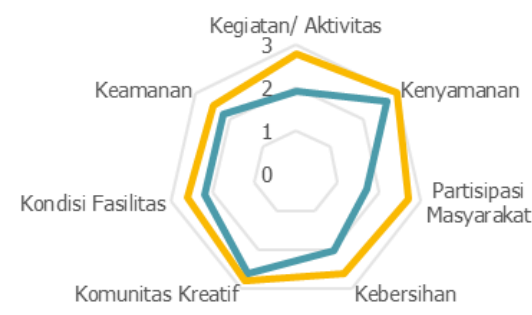

Taman Kandaga Puspa 2 Rata-rata

Gambar 16. Faktor Pengembangan Taman Kandaga Puspa

Pada Taman Kandaga Puspa, seluruh faktor pengembangan perlu diperhatikan karena nilainya yang di bawah rata-rata.

\section{Taman Cibeunying}

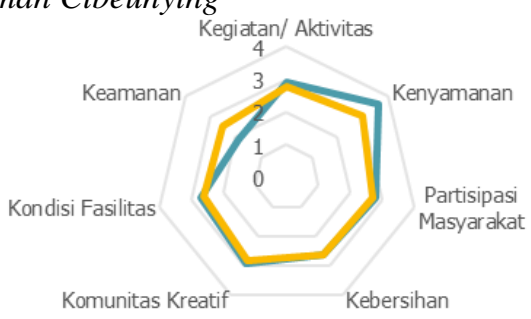

Gambar 17. Faktor Pengembangan Taman Cibeunying

Pada Taman Cibeunying, faktor pengembangangan yang perlu diperhatikan adalah faktor keamanan karena nilainya yang di bawah rata-rata.

\section{Petpark (Taman Hewan)}

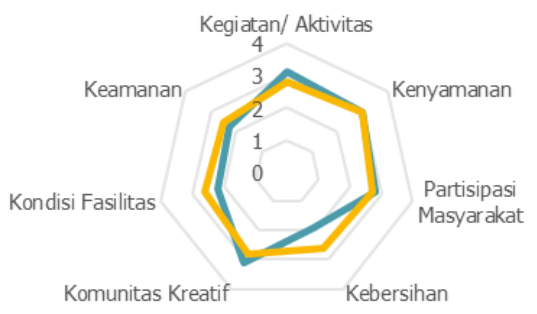

Gambar 18. Faktor Pengembangan Petpark

Pada Petpark, faktor yang perlu diperhatikan adalah faktor kebersihan, keamanan, dan kondisi fasilitas karena nilainya yang di bawah rata-rata.

5. Taman Jomblo \& Skatepark

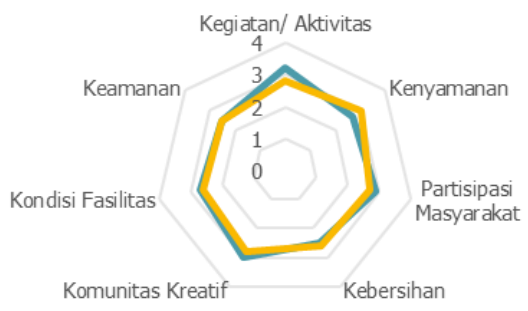

Gambar 19. Faktor Pengembangan Taman Jomblo \& Skatepark

Taman Jomblo \& Skatepark dijadikan dalam satu penilaian yang sama karena letaknya yang bersebelahan dan tidak adanya karakter khusus yang terdapat di Taman Jomblo. Faktor yang perlu diperhatikan yaitu kebersihan dan kenyamanan.

\section{Taman Film}

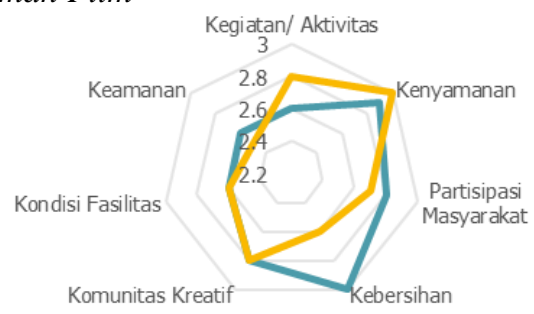

Taman Film Rata-rata

Gambar 20. Faktor Pengembangan Taman Film

Pada Taman Film, faktor pengembangan yang perlu diperhatikan adalah kegiatan/aktivitas dan kenyamanan karena nilainya yang masih di bawah rata-rata.

7. Taman Superhero

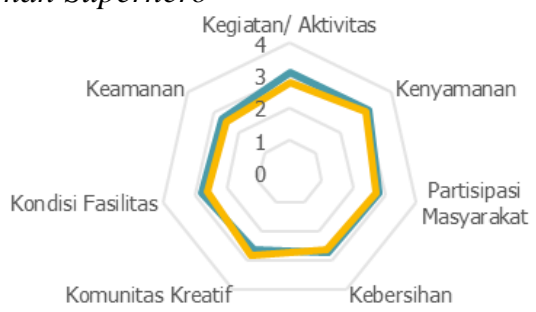

Taman Superhero Rata-rata

Gambar 21. Faktor Pengembangan Taman Superhero

Pada Taman Superhero, faktor pengembangan yang perlu diperhatikan adalah komunitas kreatif karena nilainya yang masih di bawah rata-rata.

8. Taman Persib (Lapang Supratman)

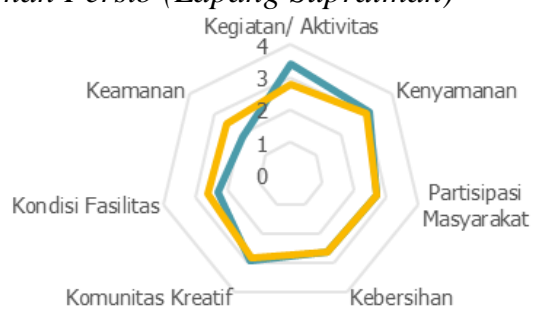

Gambar 22. Faktor Pengembangan Taman Persib

Pada Taman Persib, faktor pengembangan yang perlu diperhatikan adalah kondisi fasilitas dan keamanan karena nilainya yang masih di bawah rata-rata.

9. Taman Radio 


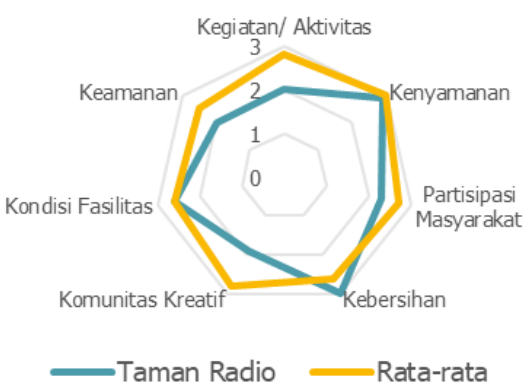

Gambar 23. Faktor Pengembangan Taman Radio

Pada Taman Radio, faktor pengembangan yang perlu diperhatikan adalah Partisipasi Masyarakat, Keamanan, Komunitas Kreatif, Kegiatan/ Aktivitas, dan Kenyamanan karena nilainya yang masih di bawah rata-rata.

\section{Taman Inklusi}

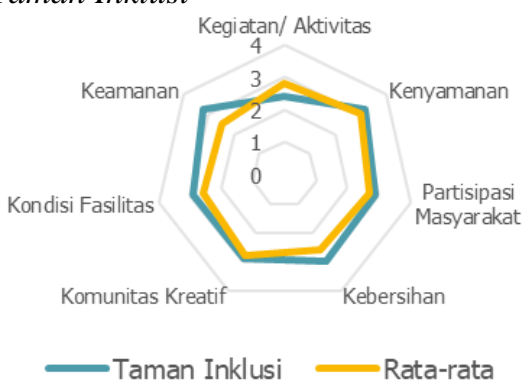

Gambar 24. Faktor Pengembangan Taman Inklusi

Pada Taman Inklusi, faktor pengembangan yang perlu diperhatikan adalah Kegiatan/Aktivitas karena nilainya yang masih di bawah rata-rata.

\section{Analisis Rumusan Arahan Pengembangan Taman} Tematik dengan Pendekatan Urban Acupuncture

Pada tahap analisis ini dilakukan Analisis Validasi Triangulasi dimana hasilnya merupakan arahan pengembangan di setiap taman tematik. Untuk melakukan analisis ini diperlukan faktor-faktor yang perlu dikembangkan di setiap tamannya berdasarkan hasil analisis di tahap sebelumnya, gambaran umum setiap taman tematik berdasarkan hasil survei primer dan sekunder, dan studi literatur atau best practice terkait taman tematik atau Urban Acupuncture. Ketiga input tersebut dipertimbangkan dalam melahirkan arahan pengembangan.

Dalam merumuskan arahan pengembangan, diperhatikan prinsip-prinsip dari Urban Acupuncture berdasarkan tinjauan pustaka adalah sebagai berikut:

Tabel 2.

Prinsip Urban Acupuncture

\begin{tabular}{cc}
\hline \hline Prinsip & Poin Penting \\
\hline $\begin{array}{c}\text { Sensitive Point } \\
\text { Small Scale }\end{array}$ & $\begin{array}{c}\text { Dalam hal ini kedua prinsip dapat diartikan sebagai } \\
\text { faktor-faktor pengembangan yang kurang dan perlu } \\
\text { dikembangkan di setiap taman tematik. }\end{array}$ \\
\hline Quick Act & $\begin{array}{c}\text { Solusi yang dapat dilakukan dari masyarakat } \\
\text { (Bottom Up) }\end{array}$ \\
\hline Scenario & Solusi yang dapat dilakukan dari pemerintah (Top \\
Down)
\end{tabular}

Poin penting dari prinsip-prinsip Urban Acupuncture menjadi pedoman dalam merumuskan arahan pengembangan di setiap taman tematik. Berikut adalah hasil rumusan arahan pengembangan di setiap taman tematik:

\section{Taman Kandaga Puspa}

- Menerapkan prinsip participation dengan mengidentifikasi kebutuhan masyarakat akan keberadaan Taman Kandaga Puspa.

- Menerapkan prinsip scenario, creating places, dan educating dengan perbaikan vegetasi pada Taman Kandaga Puspa.

- Menerapkan prinsip scenario dengan melakukan pemugaran fasilitas penunjang lainnya Taman Kandaga Puspa.

- Menerapkan prinsip scenario, holistic approaches, dan creating places dengan melibatkan arsitek lansekap, akademisi, dan komunitas tanaman hias untuk pengembangan Taman Kandaga Puspa.

- Menerapkan prinsip scenario dengan cara menambahkan fasilitas kebersihan.

- Menerapkan prinsip scenario dengan cara menambahkan dan meningkatkan fasilitas penunjang keamanan di Taman Kandaga Puspa.

- Menerapkan prinsip scenario dan holistic approaches dengan cara mengundang para komunitas tanaman hias untuk melakukan kegiatan di Taman Kandaga Puspa.

- Menerapkan prinsip quick act dan holistic approaches dengan melibatkan komunitas tanaman hias untuk menciptakan kegiatan/aktivitas di Taman Kandaga Puspa.

\section{Taman Cibeunying}

- Menerapkan prinsip scenario dengan menambahkan dan meningkatkan fasilitas penunjang keamanan di Taman Cibeunying.

- Menerapkan prinsip quick act dan holistic approaches dengan memanfaatkan kehadiran komunitas dan Pedagang Kaki Lima di sekitar Taman Cibeunying untuk menambah tingkat keamanan.

\section{Petpark (Taman Hewan)}

- Menerapkan prinsip scenario, creating places, dan educating dengan cara pemugaran fasilitas bagian dalam Taman Petpark.

- Menerapkan prinsip quick act dan holistic approaches dengan memberdayakan komunitas dalam merawat dan menjaga fasilitas hewan yang ada.

- Menerapkan prinsip scenario dengan menambahkan petugas di Taman Petpark.

- Menerapkan prinsip scenario dengan menambahkan dan meningkatkan fasilitas penunjang keamanan di Taman Petpark.

\section{Taman Jomblo \& Skatepark}

- Menerapkan prinsip scenario dengan cara menambahkan kuantitas fasilitas kebersihan di titik pusat aktivitas taman.

- Menerapkan prinsip quick act dan holistic approaches dengan cara melakukan sosialisasi pada komunitas dan 
pedagang yang tedapat di area Taman Pasupati dan Skatepark.

- Menerapkan prinsip scenario, holistic approaches, creating places, dan educating dengan melibatkan peran komunitas skateboard dalam penyediaan fasilitas taman.

\section{Taman Film}

- Menerapkan prinsip scenario, holistic approaches, creating places, dan educating dengan melibatkan komunitas film dan arsitek lansekap dalam pengembangan fasilitas penunjang kenyamanan Taman Film.

- Menerapkan prinsip quick act dan holistic approaches dengan melibatkan komunitas film dalam menciptakan event perfilman di Taman Film.

\section{Taman Superhero}

- Menerapkan prinsip scenario, holistic approaches, dan creating places dengan mengundang para komunitas anak dan orang tua untuk berkegiatan di Taman Superhero.

- Menerapkan prinsip scenario dan holistic approaches dengan bekerja sama dengan dinas/badan terkait anak untuk menghadirkan komunitas kreatif.

- Menerapkan prinsip quick act dengan bekerja sama dengan para pedagang untuk menambahkan atraksi agar menarik minat komunitas.

\section{Taman Persib}

- Menerapkan prinsip scenario dan educating dengan pemugaran fasilitas olahraga Taman Persib.

- Menerapkan prinsip quick act dengan memberdayakan komunitas BARSTARD.

- Menerapkan prinsip scenario dengan menambahkan fasilitas penunjang keamanan Taman Persib.

\section{Taman Radio}

- Menerapkan prinsip participation dengan mengidentifikasi kebutuhan masyarakat akan keberadaan Taman Radio.

- Menerapkan prinsip scenario dengan menambahkan dan meningkatkan fasilitas penunjang keamanan di Taman Radio.

- Menerapkan prinsip holistic approaches dan creating places dengan melakukan koordinasi dengan pihak PRSSNI Jawa Barat.

- Menerapkan prinsip scenario, holistic approaches, dan creating places dengan melibatan komunitas radio dan arsitektur lansekap dalam pengembangan fasilitas penunjang kenyamanan Taman Radio.

- Menerapkan prinsip quick act dengan melibatkan komunitas radio dalam menciptakan kegiatan/aktivitas di Taman Radio.

- Menerapkan prinsip scenario dengan melakukan perluasan area aktif Taman Radio.

\section{Taman Inklusi}

- Menerapkan prinsip scenario, holistic approaches, creating places, dan educating dengan menyediakan fasilitas disabilitas yang memadai dengan bekerja sama dengan arsitektur lansekap, psikolog, orang tua, dan komunitas disabilitas.

- Menerapkan prinsip quick act dengan melibatkan komunitas disabilitas dalam menciptakan kegiatan/aktivitas di Taman Inklusi.

\section{KESIMPULAN}

Berdasarkan penelitian ini dapat diketahui bahwa faktor pengembangan taman tematik di Kecamatan Bandung Wetan yaitu (1) Kegiatan/Aktivitas; (2) Kenyamanan; (3) Partisipasi Masyarakat; (4) Kebersihan; (5) Komunitas Kreatif; (6) Kondisi Fasilitas; dan (7) Kebersihan. Pada Taman Lansia tidak terdapat faktor pengembangan yang perlu diperhatikan karena dinilai telah melebihi rata-rata faktor pengembangan. Sedangkan untuk taman tematik lainnya di Kecamatan Bandung Wetan terdapat beberapa faktor pengembangan yang perlu diperhatikan. Setiap taman tematik memiliki faktor pengembangan yang berbeda untuk diperhatikan. Dari faktor-faktor pengembangan yang ada, dapat dirumuskan arahan pengembangan di setiap tamannya dengan memperhatikan prinsip-prinsip Urban Acupuncture yang ada. Secara teoretis, penelitian ini dapat dilanjutkan dengan memperdalam partisipasi masyarakat agar dapat lebih memperdalam bentuk penanganan dengan pendekatan Urban Acupuncture. Selain itu, pendekatan Urban Acupuncture dapat dilakukan dengan mengaitkan keberadaan taman tematik dengan kawasan sekitar sehingga dapat diteliti lebih lanjut terkait hubungan antara taman tematik dengan kawasan sekitarnya. Sedangkan secara praktis, hasil arahan pengembangan ini dapat dijadikan masukan bagi dinas terkait di Kota Bandung, dalam hal ini adalah Dinas Perumahan dan Kawasan Permukiman, Pertanahan dan Pertamanan (DPKP3) Kota Bandung dalam merumuskan arahan pengembangan taman tematik.

\section{UCAPAN TERIMA KASIH}

Penulis mengucapkan banyak terima kasih kepada pihakpihak terkait yang telah mendukung penelitian ini, di antaranya yaitu DPKP3 Kota Bandung dan Bappelitbang Kota Bandung. Selain itu, kepada para responden kuesioner dan juga narasumber wawancara di setiap taman tematik yang telah membantu penulis dalam mendapatkan informasi untuk mendukung penelitian ini.

\section{DAFTAR PUSTAKA}

[1] F. Naldi and - Indrianawati, "Pembangunan Geodatabase Ruang Terbuka Hijau Kota Bandung," REKA GEOMATIKA, 2018, doi: 10.26760/jrg.v2016i1.1832.

[2] F. Ilmiajayanti dan D. I. K. Dewi, "Persepsi Pengguna Taman Tematik Kota Bandung Terhadap Aksesibilitas Dan Pemanfaatannya," Ruang, vol. 1, no. 1, pp. 21-30, Jan. 2015.

[3] Bappeda, "Kajian Konsep Pengembangan dan Pengelolaan Taman Kota menjadi Taman Tematik di Kota Bandung," November 2014. [Online]. Available: https://docplayer.info/49622277-Kajian-konseppengembangan-dan-pengelolaan-taman-kota-menjadi-taman-tematikdi-kota-bandung.html.

[4] DPKP3, $2018 . \quad$ [Online]. Available: http://dpkp3.bandung.go.id/informasi/pertamanan.

[5] D. M. Sumaatmaja dan B. Pranggono, "Kajian Keberlanjutan Taman Tematik Berdasarkan Perspektif Pengunjung," Prosiding Perencanaan Wilayah dan Kota, vol. 3, no. 2, Agu. 2017. 
[6] R. E. Lestari, "Evaluasi Pemanfaatan Fungsi Taman Tematik sebagai Urban Landscape dalam Upaya Perwujudan Green City (Studi Kasus: Taman Tematik di Kota Bandung)," Skripsi, Fakultas Teknik dan Ilmu Komputer. Program Studi Perencanaan Wilayah dan Kota. Universitas Komputer Indonesia, Bandung, 2015.

[7] R. Widyahantari and I. Rudiarto, "KAPASITAS PEMERINTAH KOTA BANDUNG DALAM PENYEDIAAN TAMAN TEMATIK GUNA MEWUJUDKAN KOTA LAYAK HUNI,” J. Pengemb. Kota, 2018, doi: 10.14710/jpk.6.1.9-16.

[8] M. M. Ari, D. Zulkaidy dan P. D. Wiwik, "Evaluasi Dampak Penyediaan Taman-Taman Tematik Kota Bandung berdasarkan Persepsi Masyarakat Sekitar," Prosiding Teтu Ilmiah IPLBI, pp. 163-170, 2016.

[9] J. Lerner, Urban Acupuncture: Celebrating Pinpricks of Change that Enrich City Life, Washington: Island Press, 2014.

[10] K. Houghton, M. Foth dan E. Miller, "Urban acupuncture: Hybrid social and technological practices for hyperlocal placemaking.," Journal of Urban Technology, pp. 3-19, 2015.

[11] S. Schroeder, J. Burnis, A. Denton, A. Krasnow, T. S. Raghu, and K. Mathis, "Effectiveness of Acupuncture Therapy on Stress in a Large Urban College Population," JAMS J. Acupunct. Meridian Stud., 2017, doi: 10.1016/j.jams.2017.01.002. 